\title{
Importance of water quality on plant abundance and diversity in high-alpine meadows of the Yerba Loca Natural Sanctuary at the Andes of north-central Chile
}

\author{
Importancia de la calidad del agua sobre la abundancia y diversidad vegetal en vegas \\ altoandinas del Santuario Natural Yerba Loca en los Andes de Chile centro-norte
}

\author{
ROSANNA GINOCCHIO ${ }^{1,2 *}$, JOSEFINA HEPP $^{2}$, ELENA BUSTAMANTE $^{1}$, YASNA SILVA $^{1}$, \\ LUZ MARÍA DE LA FUENTE ${ }^{1}$, JEAN FRANCOIS CASALE ${ }^{1}$, JEAN PAUL DE LA HARPE ${ }^{1}$, \\ PAOLA URRESTARAZU ${ }^{1}$, VINKA ANIC ${ }^{3} \&$ GLORIA MONTENEGRO $^{2}$
}

\author{
${ }^{1}$ Centro de Investigación Minera y Metalúrgica, Avenida Parque Antonio Rabat 6500, Vitacura, Santiago, Chile \\ ${ }^{2}$ Facultad de Agronomía e Ingeniería Forestal, Pontificia Universidad Católica de Chile, Avenida Vicuña Mackenna 4860, \\ Macul, Santiago, Chile \\ ${ }^{3}$ Facultad de Ciencias, Universidad de Chile, Las Palmeras 3425, Nuñoa, Santiago, Chile \\ *e-mail for correspondence: rginocc@cimm.cl
}

\begin{abstract}
Porphyry $\mathrm{Cu}-\mathrm{Mo}$ deposits have influenced surface water quality in high-Andes of north-central Chile since the Miocene. Water anomalies may reduce species abundance and diversity in alpine meadows as acidic and metal-rich waters are highly toxic to plants The study assessed the importance of surface water quality on plant abundance and diversity in high-alpine meadows at the Yerba Loca Natural Santuary (YLNS), central Chile $\left(33^{\circ} 15^{\prime} \mathrm{S}, 70^{\circ} 18^{\prime} \mathrm{W}\right)$. Hydrochemical and plant prospecting were carried out on Piedra Carvajal, Chorrillos del Plomo and La Lata meadows the growing seasons of 2006 and 2007. Direct gradient analysis was performed through canonical correspondence analysis (CCA) to look for relationships among water chemistry and plant factors. High variability in water chemistry was found inside and among meadows, particularly for $\mathrm{pH}$, sulphate, electric conductivity, hardness, and total dissolved $\mathrm{Cu}, \mathrm{Zn}, \mathrm{Cd}, \mathrm{Pb}$ and $\mathrm{Fe}$. Data on species abundance and water chemical factors suggests that $\mathrm{pH}$ and total dissolved $\mathrm{Cu}$ are very important factor determining changes in plant abundance and diversity in study meadows. For instance, Festuca purpurascens, Colobanthus quitensis, and Arenaria rivularis are abundant in habitats with $\mathrm{Cu}-\mathrm{rich}$ waters while Festuca magellanica, Patosia clandestina, Plantago barbata, Werneria pygmea, and Erigeron andicola are abundant in habitats with dilute waters.
\end{abstract}

Key words: porphyry deposits, phytotoxicity, plant diversity, acid mine drainage, copper toxicity.

\section{RESUMEN}

Los megadepósitos de pórfidos de $\mathrm{Cu}-\mathrm{Mo}$ han influido sobre la calidad de las aguas superficiales en las zonas altoandinas del centro-norte de Chile desde el Mioceno. Estas alteraciones en la calidad de las aguas podrían afectar negativamente a la vegetación presente en las vegas altoandinas, ya que las aguas ácidas y ricas en metales son altamente tóxicas para las plantas. En este estudio se evaluó el efecto de la calidad de las aguas en la abundancia y diversidad florística de las vegas altoandinas del Santuario de la Naturaleza Yerba Loca (SNYL), en Chile central $\left(33^{\circ} 15^{\prime} \mathrm{S}, 70^{\circ} 18^{\prime} \mathrm{O}\right)$. Se realizaron prospecciones hidroquímicas y botánicas en las vegas de Piedra Carvajal, Chorrillos del Plomo y La Lata, durante las estaciones de crecimiento de 2006 y 2007. Se realizó un análisis directo de gradiente a través del Análisis de Correspondencia Canónica (CCA) para buscar relaciones entre los parámetros químicos del agua y los parámetros botánicos. Se encontró una alta variabilidad química del agua tanto dentro como entre las vegas, particularmente en cuanto a pH, sulfatos, conductividad eléctrica, dureza y contenidos totales disueltos de $\mathrm{Cu}, \mathrm{Zn}, \mathrm{Cd}, \mathrm{Pb}$ y $\mathrm{Fe}$. Los datos de abundancias específicas y los parámetros químicos del agua sugieren que el pH y el contenido de $\mathrm{Cu}$ total disuelto son factores importantes en determinar los cambios en la abundancia y la diversidad de las especies vegetales en las vegas estudiadas. Por ejemplo, Festuca purpurascens, Colobanthus quitensis y Arenaria rivularis son abundantes en ambientes de aguas con altos contenidos de $\mathrm{Cu}$, mientras que Festuca magellanica, Patosia clandestina, Plantago barbata, Werneria pygmea y Erigeron andicola son abundantes en lugares de aguas con bajos contenidos de $\mathrm{Cu}$.

Palabras clave: depósitos porfíricos, fitotoxicidad, diversidad vegetal, drenaje ácido de mina, toxicidad por cobre. 


\section{INTRODUCTION}

Alpine meadows along streams are frequent in the Andes of north-central Chile (i.e., Ruthsatz 1993, Hoffmann et al. 1998, Arroyo et al. 2002, Cepeda et al. 2006, Squeo et al. 2006a). These landscape units are key components of the Andean ecosystems; they provide important habitat and resources for wildlife and trashumant livestock as they represent permanent water sources with high plant cover (70-100 \%) and high floral and faunal diversity (Hoffmann et al. 1998, Cepeda \& Morales 2006, Cepeda et al. 2006, Osorio et al. 2006, Squeo et al. 2006b, 2006c).

These azonal systems represent biogeographic islands scattered on the xeromorphic landscape of the alpine Mediterranean flora of the Andes of north-central Chile, as they markedly differ on their ecosystem structure and dynamic. Indeed, formation, persistence, size, and function of alpine meadows are more related to hydrologic processes than climatic conditions (Ruthsatz 1995, Carter 1996, Körner 2003, Osorio et al. 2006). According to Ruthsatz (1995), Alpine meadows located in north-central Chile most commonly are ground-water and surface-water discharge areas on slope breaks and depressions of mountain valleys derived from rain and snowmelt. Duration and seasonality of flooding and soil saturation, soil type, water chemistry, and drainage characteristics exert strong influence on the number, type, and distribution of plant species both among and inside alpine meadows (Chambers 1997, Körner 2000, Squeo et al. 2006b) as it also has commonly been described for lowland freshwater wetlands (Carter 1996). For example, differences in soil moisture and salinity have been normally described as abiotic factors that determine species distribution on alpine meadows, thus influencing the location of dry and moist alpine meadows (Chambers 1997, Körner 2003, Squeo et al. 2006b).

Plant abundance and distribution in freshwater wetlands has generally been related to water chemistry among other abiotic factors (Ehrenfeld \& Schneider 1991, Carter 1996). Indeed, most floristic variation within northwest European wetland vegetation has been accounted for by water $\mathrm{pH}$ gradients (Wheeler \& Proctor 2000). Studies on wetlands with secondary acidification of waters due to human activities in Great Britain have shown that acidified wetlands result in highly impoverished vegetation with only some abundant plants such as the purple moor grass (Molinia cerulea) or the development of carpets of Sphagnum moss (Wheeler et al 2002). Metal content in surface waters has also been described as a factor determining plant distribution in wetlands. For example, Juncus subnodulosus dominates areas with high concentrations of iron in base-rich wetlands in Great Britain while Epilobium hirsutum is not present in those areas (Wheeler et al. 1985). Therefore, it has been suggested that plants can serve as indicators of wetland hydrochemistry (Ehrenfeld \& Schneider 1991, Denninson et al. 1993)

In general, streams in high-elevation basins of world alpine areas are dilute because fast hydrologic flushing rates and minimal soil development limit interaction among high-flow discharge (spring snowmelt) and geologic materials that weather relatively slowly (Clow \& Sueker 2000). However, relations among surface water chemistry and selected basin characteristics have been described in a number of studies. For example, several studies document that basins underlain predominantly by calcareous rocks tend to have surface water with higher alkalinity than basins with mostly noncalcareous rocks (Puckett \& Bricker 1992, Rice \& Bricker 1995). Brooks et al. (2001) document elevated concentrations of $\mathrm{Zn}$ and sulphate during snowmelt along some streams in Summit, Colorado, USA, due to historic mining and widely disseminated pyrite in the host rock of the catchments.

In the high-Andes of north-central Chile, a large porphyry copper-molybdenum ( $\mathrm{Cu}-\mathrm{Mo})$ deposit (32-34 S; Skewes \& Stern 1994a, 1994b) have influenced surface water quality in this alpine area since the late Miocene and early Pliocene (Henríquez 1974), such as in the Yerba Loca Natural Santuary (YLNS, $33^{\circ} \mathrm{S}, 70^{\circ} \mathrm{W}$; Barceló 1984). Specifically, a large porphyry copper deposit $\left(>40 \mathrm{~km}^{2}\right)$ with secondary formation of tourmaline and copper-zincmolybdenum sulphides exist at high elevations of the Yerba Loca basin (Bassi 1982, Serrano et al. 1994, Stambuk et al. 1994') which have long

\footnotetext{
STAMBUK V, C HOLMGREN, R VARGAS, A CONTRERAS, L SERRANO, S GODOY, M GALEB \& I VELA (1994) Geología del megayacimiento Río Blanco - Los Bronces Chile central. Actas $7^{\circ}$ Congreso Geológico Chileno, Universidad de Concepción, Concepción, Chile.
} 
influenced surface water quality of streams in the area, particularly in terms of $\mathrm{pH}$, sulphate content and mineral concentrations. For instance, the main stream along the YLNS is called Yerba Loca and it has acidic (4.1-5.3) and high sulphate $\left(>150 \mathrm{mg} \mathrm{L}^{-1}\right)$ and metal content waters (3.6-9.1 mg L-1 of $\mathrm{Cu}$ and $0.2 \mathrm{mg}$ $\mathrm{L}^{-1}$ of $\mathrm{Zn}$; R. Ginocchio unpublished data). These marked hydrochemical gradients in surface water may have an important role in structuring plant communities at meadows of the YLNS, as acidic and metal-rich waters are highly toxic to most plant species (Fernándes \& Henríques 1991, Adriano 2001, Ginocchio et al. 2002, Ginocchio \& Baker 2004).

Even though differences on plant abundance and distribution have been described on alpine meadows of the Andes in north-central Chile, such as the occurrence of two main plant formations, grass-dominated meadows (i.e., Deschampsia caespitose, Deyeuxia velutina) and juncaceae cushion-like dominated meadows (i.e., Patosia clandestina, Oxychloe andina, Juncus balticus; Gajardo 1994, Squeo et al. 1999, 2006c, Luebert \& Pliscoff 2006), scarce information exists on the importance of water chemistry on plant abundance and distribution, both inside and among alpine meadows. Therefore, the aim of this study was to assess the importance of water quality on plant abundance and distribution on high-alpine meadows at the YLNS as case study site.

\section{MATERIAL AND METHODS}

\section{Study site}

The study was conducted in high-alpine areas of the Yerba Loca Natural Sanctuary (YLNS), the Andes of central Chile $\left(33^{\circ} 15^{\prime} \mathrm{S}, 70^{\circ} 18^{\prime}\right.$ W). The area has Mediterranean influence, a 5to 8-months snow-free growing season that typically extends from mid-October to midMay (di Castri \& Hajek 1976). Mean total annual precipitation at $2,500 \mathrm{~m}$ of altitude is about $445 \mathrm{~mm}$, falling predominately as snow between May and September (Santibáñez \& Uribe 1993). Mean monthly air temperature during the growing season ranges from $7{ }^{\circ} \mathrm{C}$ in April to $12{ }^{\circ} \mathrm{C}$ in February at 2,600 $\mathrm{m}$ of altitude (Cavieres \& Arroyo 1999).
Three high-alpine meadows along the YLNS were selected for the study: Piedra Carvajal, Chorrillos del Plomo and La Lata (Fig. 1). They represent varied elevations $(2,800$ to $3,300 \mathrm{~m})$, sizes $\left(5,755\right.$ to $\left.23,180 \mathrm{~m}^{2}\right)$ and downstream water sources from the Río Blanco-Los Bronces-Yerba Loca Cu-Mo deposit (Yerba Loca stream, upstream and downstream Chorrillos del Plomo confluence, and Chorrillos del Plomo stream, Fig. 1). Chorrillos del Plomo meadow is located in an open high-altitude terrace and is mainly drained by the main stream (Chorrillos del Plomo) while the other meadows are drained by the Yerba Loca stream but also by the water draining though the steep valley side slopes. An area of the north side of La Lata meadow is also influenced by the acid mine drainage (AMD) being generated by a nearby abandoned sterile pile of a historic small-scale silver exploitation (Fig. 1). Therefore, marked gradients in water chemistry are expected inside and among study meadows.

\section{Vegetation sampling}

A number of sampling points per meadow (nine at Piedra Carvajal, 10 at Chorrillos del Plomo and 6 at la Lata) were systematically selected and georreferenced from aerial and satellite photographs in order to cover all meadow surfaces. Sampling points were located in the field with a GPS (Garmin, etrex Venture) and characterized in terms of plant richness and cover during the growing seasons of 2006 and 2007. A $2.5 \times 2.5 \mathrm{~m}\left(5 \mathrm{~m}^{2}\right)$ quadrant was established in every sampling point and the identity of all plant species and the proportion of the quadrant area occupied by the different species were registered; plant cover was estimated with the Braun-Blanquet method as described by Kent \& Coker (1994). Plant cover scales were + , less than $1 \%$ cover; $1,1-5 \% ; 2$, 6-25\% cover; 3, 26-50\%; 4, 51-75\% cover; 5 , $76-100 \%$ cover. Additionally, a census of all the species present on study meadows was conducted in order to generate a floristic list of the species. Plant taxonomy followed $w^{3}$ TROPICOS, Missouri Botanical Garden (http://mobot.mobot.org/W3 T/Search/ vast.html) and Correa (1978). Plant species were classified according to origin and life form classification of Raunkiaer (1937). 


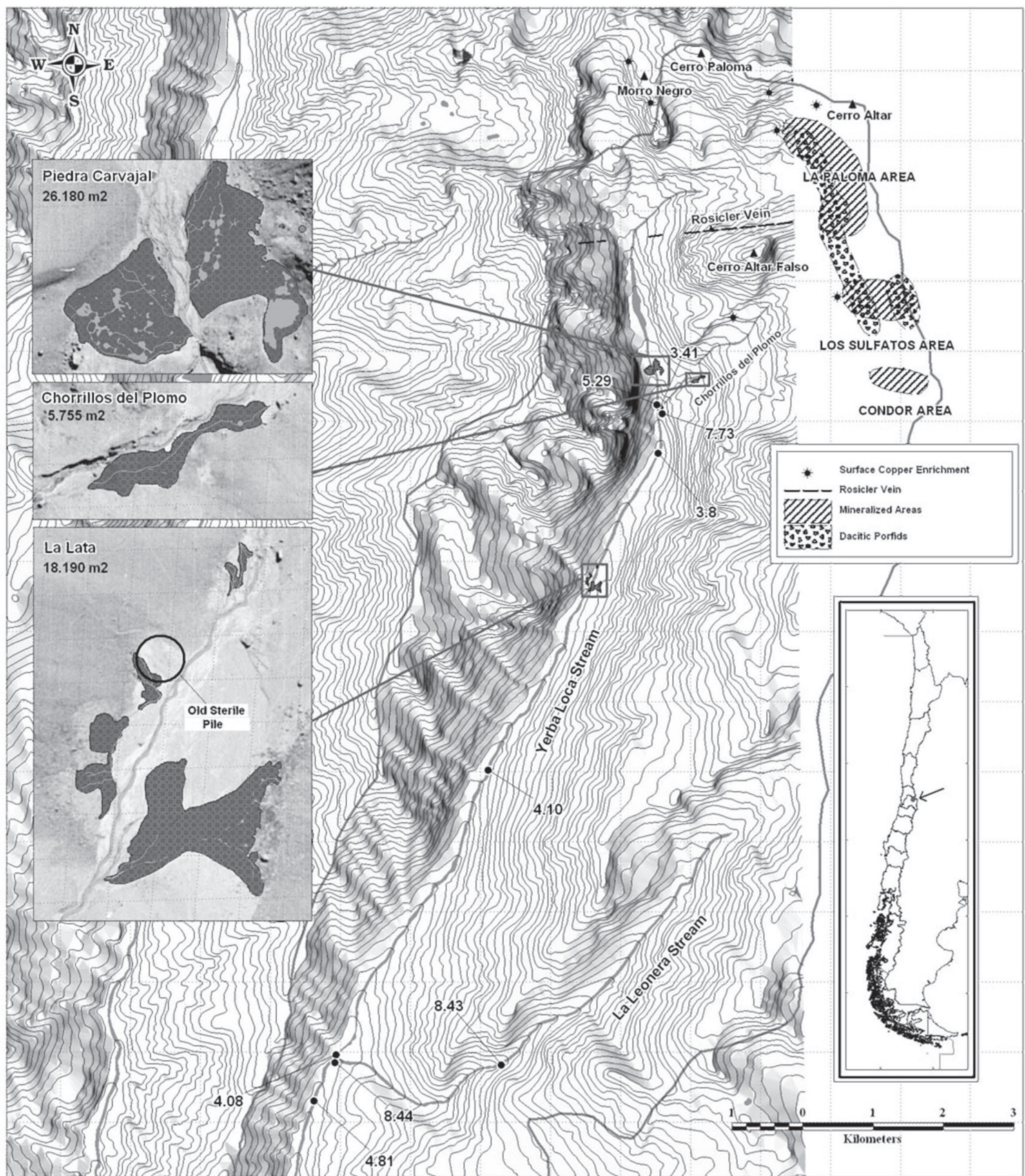

Fig. 1: Location of Yerba Loca Natural Sanctuary (YLNS) in central Chile. Relative distribution of study high-alpine meadows, high-altitude mineral deposits and abandoned sterile pile from historic small-scale silver exploitation is indicated. Numbers in the map indicate $\mathrm{pH}$ values of surface water.

Ubicación del Santuario de la Naturaleza Yerba Loca (SNYL) en Chile central. Se indica la distribución relativa de las vegas altoandinas estudiadas, los depósitos minerales en altura y un botadero abandonado, producto de la explotación histórica de plata a pequeña escala en la zona. Los números en el mapa indican valores de pH de las aguas superficiales. 
Aerial shoots of selected plant species were collected at 10 sampling sites with different water qualities in all three alpine meadows for metal determinations (copper, $\mathrm{Cu}$, zinc, $\mathrm{Zn}$, and iron, Fe). Samples were carried out to the laboratory, washed with ultrapure water $(>18$ $\mathrm{M} \Omega / \mathrm{cm})$ to eliminate soil particles that were adsorbed on plant tissue surfaces (Steubing 1982). Shoots were then air dried at $45^{\circ} \mathrm{C}$ to a constant weight and $\mathrm{Cu}, \mathrm{Zn}$, and $\mathrm{Fe}$ contents were determined as described below.

\section{Water sampling}

Water samples were taken from all vegetation sampling point (were possible) with acidwashed polyethylene plastic vials $(50 \mathrm{~mL})$. An extra number of sites were also sampled (43 at Piedra Carvajal, 13 at Chorrillos del Plomo and 30 at la Lata) as all three study meadows may receive water from more than one source (i.e., ground-water from one or several slopes and surface water from streams). Method 1638 of the U.S. Environmental protection Agency (United States EPA: 1996; http://www.epa.gov/ cgi-bin/claritgw?op-display\&document=clserv: OW:0569;rank=4\&template=epa) was used for the acid-washing of all polyethylene containers (24 h with $0.5 \%$ Extran $\mathrm{MA} \mathrm{O}_{2}$ neutral (Merk, Darmstadt, Germany), 24 h with $1 \mathrm{~N} \mathrm{HNO}_{3}, 24$ $h$ with $1 \mathrm{~N} \mathrm{HCl}$, and four washings with ultrapure water $(>18 \mathrm{M} \Omega / \mathrm{cm})$ ). The $\mathrm{pH}$ and EC determinations were done in the field up to 5 min after sample collection with a portable $\mathrm{pH} / \mathrm{EC}$ tester (Hanna Instruments HI98130) which includes a combination $\mathrm{pH}$ electrode and a conductivemeter. Vials were closed and kept in double polyethylene plastic bags with hermetic seal according to method 1669 , Sampling Ambient Water for Trace Metals at U.S. EPA Water Quality Criteria Levels (U.S. EPA 821-R-95-034, April 1995). Vials were carried out to the laboratory for general chemical determinations as described below.

\section{Chemical characterization of water and plant tissues}

Water samples were divided in two aliquots; one was acidified with $5 \% \mathrm{HNO}_{3}$ Suprapur (Merk) for elemental determinations. All samples and aliquots were kept at $5{ }^{\circ} \mathrm{C}$ until analysis. Sulphate concentration was determined under the United States EPA 300 method with an ionic chromatograph DIONEX 120X. Calcium (Ca) and magnesium ( $\mathrm{Mg}$ ) concentrations were determined with the United States EPA 251.1 and 242.1 methods, respectively, using an AAS (Perkin Elmer AAnalyst 300). Water hardness was estimated from $\mathrm{Ca}$ and $\mathrm{Mg}$ contents according to Clesceri et al. (1998). Total dissolved copper $(\mathrm{Cu})$, zinc $(\mathrm{Zn})$, cadmium $(\mathrm{Cd})$, lead $(\mathrm{Pb})$ and iron $(\mathrm{Fe})$ in water samples were determined using an inductively coupled plasma-mass spectrometer (ICP-MS; ELAN 6100 with autosampler AS90; Perkin-Elmer, Uberlinger, Germany) following U.S. EPA method SW-486 (U.S. EPA 1997). The standard calibration solution used was ICP-MS multielements, $99.99 \%$ purity, high purity, and reference material ION-20 (National Water Research Institute, Burlington, Ontario, Canada). Sample, calibration standards, and reference material were in $0.2 \% \mathrm{HNO}_{3}$.

Dried shoot tissues were finely crushed in a Restsch S100 agate ball mill (Newton, Pennsylvania, USA) and digested after a modified United States EPA protocol (United States EPA 1996). Every digestion batch included one blank sample, one standard reference material (SRM) sample (SRM 1573a tomato leaves; National Institute of Standards and Technology, Gaithersburg, Maryland, USA), one duplicated sample, and one qualitycontrol sample for the quality-assurance and control criteria. Metals were analyzed by ICPMS (ELAN 6100 with autosampler AS90; Perkin-Elmer, Uberlinger, Germany).

\section{Copper tolerance testing}

Tolerance of Festuca purpurascens to copper was tested using standard dose-response metal testing in hydroponic culture as described by Schat \& Ten Bookum (1992) and Harper (1996), as this species thrives in a broad range of water qualities in all study alpine meadows. Seeds of $F$. purpurascens were collected from individuals growing at different water quality sites at La Lata and Piedra Carvajal meadows as indicated in Table 1. Stock plants were grown in perlite supplemented with mineralized water and kept in a plant growth room until roots reached $>1$ cm-length. They were then transferred to $1-\mathrm{L}$ polyethylene containers provided with a polystyrene floater with 6 perforations in which 
the seedlings were plugged with a piece of polystyrene. The nutrient solution (1/5th strength Hoagland nutrient solution according to Harper 1996) was continuously aerated. Its composition was: $0.2 \mathrm{mM} \mathrm{MgSO}_{4} * 7 \mathrm{H}_{2} \mathrm{O}, 0.5$ $\mathrm{mM} \mathrm{Ca}\left(\mathrm{NO}_{3}\right)_{2} * 4 \mathrm{H}_{2} \mathrm{O}, 0.5 \mathrm{mM} \mathrm{KNO} 3,0.1 \mathrm{mM}$ $\mathrm{K}_{2} \mathrm{HPO}_{4} * 3 \mathrm{H}_{2} \mathrm{O}, 0.2 \mu \mathrm{M} \mathrm{CuSO} \mathrm{Cu}_{4} * 5 \mathrm{H}_{2} \mathrm{O}, 0.2$

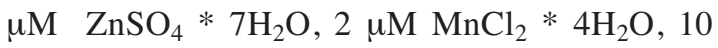
$\mu \mathrm{M} \quad \mathrm{H}_{3} \mathrm{BO}_{3}, 0.1 \mu \mathrm{M} \quad \mathrm{MoO}_{3}$, and $10 \mu \mathrm{M}$ FeEDDHA. After 3 weeks of acclimatization to the new culture conditions, the tests were started. The length of the longest root was measured per seedling and the nutrient solution was replaced by a test solution of a similar composition that was spiked with $0,0.125,0.5$, 1.0 and $2.0 \mathrm{mg} \mathrm{L}^{-1}$ of $\mathrm{Cu}$ as $\mathrm{CuSO}_{4} * 5 \mathrm{H}_{2} \mathrm{O}$. Two to three replicated containers were used per treatment with a total of 12 or 18 seedlings per treatment, respectively. Test solutions were changed every two days to keep constant concentrations of nutrients and $\mathrm{Cu}$. Containers were placed into a plant growth room under controlled temperature $\left(23 \pm 2{ }^{\circ} \mathrm{C}\right)$, photoperiod regime (day/night 12/12 h) and light intensity $\left(103 \pm 14.3 \mu \mathrm{m} \mathrm{s}^{-1} \mathrm{~m}^{-2}\right)$. After seven days of experimentation, the length of the longest root was measured per seedling and the root elongation per plant was estimated.

\section{Data analysis}

Univariate non-parametric procedures were used to analyze variation in water chemistry parameters among meadows and among sampling sites (Zar 1984). The Kruskal-Wallis ANOVA by ranks test was used to compare water chemical parameters among meadows and to compare root elongation of $F$. purpurascens plants under the metal tolerance tests. Spearman correlations were used to evaluate relations among water chemistry factors in all sampling sites, to evaluate relations among water chemical parameters and plant richness of sampling sites, and to evaluate relations among metal content in shoots and metal contents in waters (Draper \& Smith 1998). All analyses were performed with the Statistica 6.0 software.

A phytosociological classification of the flora identified at the 25 sampling sites was performed for exploratory analyses of plant associations, following the Braun-Blanquet system described by Kent \& Coker (1994), as it was not always possible to take water samples from the sampling sites for a direct gradient analysis. A tabular comparison and sorting of sampling sites through identification of good differential species was performed after calculation of their degree of constancy (number of sampling points in which a given species occurs); differential species have intermediate ranges of constancy and tend to occur together in several sampling points but are absent or only sparingly present in the others, thus allowed formation of groups of floristic similarity.

Canonical correspondence analysis (CCA; Ter Braak 1986, Jongman et al. 1995) was used

TABLE 1

Water quality of high-alpine meadow sites at YLNS where seeds of Festuca purpurascens where collected for copper tolerance testing

Calidad del agua de las vegas altoandinas del SNYL donde se colectaron semillas de Festuca purpurascens para los ensayos de tolerancia a cobre

\begin{tabular}{|c|c|c|c|c|c|c|c|c|c|c|}
\hline \multirow[t]{2}{*}{ Meadow-site } & \multirow{2}{*}{$\begin{array}{l}\text { Altitude } \\
\text { (m) }\end{array}$} & \multirow[t]{2}{*}{$\mathrm{pH}$} & \multirow{2}{*}{$\begin{array}{c}\mathrm{EC} \\
\left(\mathrm{mS} \mathrm{cm}^{-1}\right)\end{array}$} & \multirow{2}{*}{$\begin{array}{l}\text { Sulphate } \\
\left(\mathrm{mg} \mathrm{L}^{-1}\right)\end{array}$} & \multirow{2}{*}{$\begin{array}{c}\text { Hardness } \\
\left(\mathrm{mg} \mathrm{L} \mathrm{CaCO}_{3}^{-1}\right)\end{array}$} & \multicolumn{5}{|c|}{ Total dissolved metal $\left(\mathrm{ug} \mathrm{L}^{-1}\right)$} \\
\hline & & & & & & $\overline{\mathrm{Cu}}$ & $\mathrm{Zn}$ & $\mathrm{Cd}$ & $\mathrm{Pb}$ & $\mathrm{Fe}$ \\
\hline La Lata-Clear waters (V37) & 2,804 & 7.97 & 0.36 & 90 & 208 & 34 & 20 & 0.1 & 0.1 & 12 \\
\hline La Lata-Mine spoil (U5) & 2,823 & 5.13 & 0.62 & 292 & 401 & 5,959 & 328 & 0.8 & 2.6 & 19 \\
\hline La Lata-Milky waters (L33) & 2,826 & 4.30 & 0.53 & 211 & 333 & 2,935 & 149 & BDL & 0.3 & 20 \\
\hline $\begin{array}{l}\text { Piedra Carvajal-Acidic/Cu-rich } \\
\text { waters (K17) }\end{array}$ & 3,247 & 5.33 & 0.41 & 249 & 225 & 1,120 & 78 & 0.2 & 0.6 & 8 \\
\hline
\end{tabular}

EC, electric conductivity; BDL, below detection limit

EC, conductividad eléctrica; BDL, bajo límite de detección 
to investigate relationships between water chemistry parameters and plant species abundance (direct gradient analysis) using data collected in a total number of 13 sampling sites (six at Piedra Carvajal, four at Chorrillos del Plomo and three at La Lata meadow). Speciesspecific absolute cover according to BraunBlanquet classification (Kent \& Coker (1994) was included in the analysis while water quality variables included were $\mathrm{pH}$, sulphate, total dissolved $\mathrm{Cu}$, and total dissolved Fe. Metal contents in waters were $\ln$ transformed. The ordination analysis was conducted using CANOCO software for windows version 4.5 (Biometrics - Plant Reseach International, Wageningen, The Netherlands; Ter Braak \& Šmilauer 2002). Detrended correspondence analysis (DCA) was used for exploratory analyses of plant abundance - water quality relations with CANOCO software for either unimodal or linear models (Ter Braak 1995, Ter Braak \& Šmilauer 2002). DCA gradient lengths were 5.2 standard deviations for the first axis, suggesting that the unimodal model was appropriate (Ter Braak \& Smilauer 2002). CCAs were subsequently used. CCAs were performed using default settings in CANOCO and Monte Carlo permutation tests were performed to evaluate the significance of the plant abundance - water quality relationships (H0, no linear relationship between species and water quality matrices) using 499 permutations under full model, one based on the first canonical eigenvalue and one based on the sum of all canonical eigenvalues (Ter Braak 1986, Ter Braak \& Smilauer 2002). All selected water parameters were included in a forwardselection model to determine the contribution of each water quality parameter to the ordination model according to an unrestricted partial Monte Carlo permutation test (Lepš \& Smilauer 2003).

\section{RESULTS}

\section{Water chemistry}

Water chemistry factors of study high-alpine meadows are shown in Table 2. Significant differences were found among meadows for mean $\mathrm{pH}$, electric conductivity (EC), sulphate, hardness, and total dissolved $\mathrm{Cu}$ and $\mathrm{Zn}$ values. Specifically, water at Chorrillos del Plomo

TABLE 2

General water chemistry characteristics of the three high-alpine meadows at the YLNS, central Chile

Características químicas generales de las aguas de las tres vegas altoandinas del SNYL, en Chile central

\begin{tabular}{|c|c|c|c|c|c|c|c|c|c|c|c|}
\hline \multirow[t]{2}{*}{ Meadow } & & \multirow{2}{*}{$\begin{array}{r}\text { Altitude } \\
(\mathrm{m})\end{array}$} & \multirow[t]{2}{*}{$\mathrm{pH}$} & \multirow{2}{*}{$\begin{array}{r}\mathrm{EC} \\
\left(\mathrm{mS} \mathrm{cm}^{-1}\right)\end{array}$} & \multirow{2}{*}{$\begin{array}{l}\text { Sulphate } \\
\left(\mathrm{mg} \mathrm{L}^{-1}\right)\end{array}$} & \multirow{2}{*}{$\begin{array}{r}\text { Hardness } \\
\left(\mathrm{mg} \mathrm{L} \mathrm{CaCO}_{3}^{-1}\right)\end{array}$} & \multicolumn{5}{|c|}{ Total disolved Metal $\left(\mu \mathrm{g} \mathrm{L}^{-1}\right)$} \\
\hline & & & & & & & $\mathrm{Cu}$ & $\mathrm{Zn}$ & $\mathrm{Cd}$ & $\mathrm{Pb}$ & $\mathrm{Fe}$ \\
\hline \multirow[t]{5}{*}{ Piedra Carvajal } & Mean & 3,256 & 7.60 & 0.38 & 160.3 & 168.6 & 475.5 & 29.4 & 0.15 & 0.25 & 55.8 \\
\hline & SD & & 1.50 & 0.23 & 125.1 & 132.2 & 690.2 & 29.9 & 0.14 & 0.27 & 130.5 \\
\hline & $\operatorname{Max}$ & & 10.81 & 0.89 & 396.7 & 475.0 & 1970.0 & 78.0 & 0.50 & 0.80 & 403.0 \\
\hline & Min & & 4.72 & 0.08 & 31.0 & 40.0 & 1.0 & 3.0 & 0.07 & 0.03 & 3.0 \\
\hline & $\mathrm{N}$ & & 52 & 52 & 9 & 9 & 9 & 9 & 9 & 9 & 9 \\
\hline \multirow[t]{5}{*}{ Chorrillos del Plomo } & Mean & 3,265 & 5.60 & 0.70 & 327.5 & 499.4 & 40.7 & 114.7 & 0.32 & 0.24 & 38.3 \\
\hline & SD & & 0.69 & 0.10 & 27.5 & 30.4 & 23.6 & 13.3 & 0.10 & 0.03 & 7.2 \\
\hline & Max & & 6.50 & 1.00 & 358.0 & $523-0$ & 67.0 & 126.0 & 0.40 & 0.30 & 45.0 \\
\hline & Min & & 3.96 & 0.59 & 320.0 & 465.0 & 22.0 & 100,0 & 0.20 & 0.20 & 31.0 \\
\hline & $\mathrm{N}$ & & 23 & 23 & 3 & 3 & 3 & 3 & 3 & 3 & 3 \\
\hline \multirow[t]{5}{*}{ La Lata } & Mean & 2,810 & 6.43 & 0.42 & 82.9 & 81.1 & 2579.3 & 138.6 & 032 & 1.02 & 18.9 \\
\hline & SD & & 1.42 & 0.15 & 82.9 & 81.1 & 2579.3 & 138.6 & 0.32 & 1.02 & 18.9 \\
\hline & $\operatorname{Max}$ & & 8.70 & 0.69 & 300.6 & 401.0 & 6006.0 & 337.0 & 0.80 & 2,60 & 73.0 \\
\hline & Min & & 4.30 & 0.21 & 90.1 & 176.0 & 10,0 & 7.0 & 0.07 & 0.10 & 10.0 \\
\hline & $\mathrm{N}$ & & 36 & 36 & 9 & 9 & 9 & 9 & 9 & 9 & 9 \\
\hline & $\mathrm{df}$ & & 2 & 2 & 2 & 2 & 2 & 2 & 2 & 2 & 2 \\
\hline \multirow{2}{*}{ ANOVA by ranks } & $\mathrm{H}$ & & 27.04 & 36.35 & 6.29 & 11.04 & 7.32 & 8.75 & 5.02 & 3.90 & 5.41 \\
\hline & $\mathrm{P}$ & & $<0.01$ & $<0.01$ & $<0.05$ & $<0.01$ & $<0.05$ & $<0.05$ & 0.08 & 0.14 & 0.07 \\
\hline
\end{tabular}


meadow is more acidic and has higher EC, hardness and sulphate values than the other ones. Water of La Lata meadow is slightly acidic and have high levels of total dissolved $\mathrm{Cu}$ and $\mathrm{Zn}$ while water of Piedra Carvajal meadow is neutral and has intermediate EC and total dissolved $\mathrm{Cu}$ levels. In general, each study meadows show high variability in water chemistry (Table 2), particularly in terms of $\mathrm{pH}$ (two to six orders of magnitude), EC (one order of magnitude), sulphate (one order of magnitude), hardness (one order of magnitude), total dissolved $\mathrm{Cu}$ (one to three orders of magnitude) and total dissolved $\mathrm{Zn}$ (one order of magnitude).

There are some significant relations among water chemistry factors as shown in Table 3. Indeed, EC of water is significantly and positively correlated to sulphate, hardness, and total dissolved $\mathrm{Zn}$ and $\mathrm{Cd}$ while sulphate is significantly and positively correlated to hardness and total dissolved $\mathrm{Zn}$ and $\mathrm{Cd}$ (Table $3)$; total dissolved $\mathrm{Cu}$ is significantly and positively correlated to total dissolved $\mathrm{Zn}, \mathrm{Cd}$, and $\mathrm{Pb}$ and concentration of all these metals is significantly and negatively correlated to $\mathrm{pH}$ (Table 3). In other words, concentration of $\mathrm{Cu}$, $\mathrm{Zn}, \mathrm{Cd}$, and $\mathrm{Pb}$ increases with increasing water acidity while salinity (measured as EC) increases with sulphate contents and hardness of water.

\section{Flora and vegetation}

Total richness of study high-alpine meadows at YLNS reached 32 vascular plant species belonging to 19 families and 26 genuses (Table 4). A number of two non-vascular species (bryophytes) were also identified but they were not taxonomically classified to the species level. Species richness varies among meadows from 14 to 18 , being higher in the smaller one (18 species at Chorrillos del Plomo, Table 5). Chorrillos del Plomo meadow has the highest number of unique species (not shared with the other two meadows) and a total number of only three species is shared by all three study meadows (Table 5). Native plant species dominates the flora of study high-alpine meadows $(85 \%)$ while endemic and exotic species are less common (3 and $6 \%$, respectively). In terms of the plant life forms, hemicryptophytes are the most common $(88 \%)$ while therophytes $(6 \%)$ and nanophanerophytes $(6 \%)$ are less represented. Total plant cover of study meadows is high (53 to $88 \%$, Table 5) in comparison with zonal vegetation found in highalpine areas of central Chile.

Results of the classification analysis indicate that vascular plant species of study meadows at YLNS can be grouped into three plant associations or groups. Group I is located among 3,147 and $3,265 \mathrm{~m}$ of altitude and is represented

TABLE 3

Spearman correlation coefficients $\left(\mathrm{r}_{\mathrm{s}}\right)$ among water chemistry parameters of sampling sites at the three high-alpine meadows of the YLNS, central Chile; $\mathrm{n}=21$, bold numbers are correlations statistically significant at $\mathrm{P}<0.05$

Coeficientes de correlación de Spearman $\left(\mathrm{r}_{\mathrm{s}}\right)$ entre parámetros químicos del agua de los sitios de muestreo en las tres vegas altoandinas del SNYL, en Chile central; $\mathrm{n}=21$, los números destacados en negro corresponden a correlaciones significativas $\mathrm{P}<0,05$

\begin{tabular}{|c|c|c|c|c|c|c|c|c|c|c|}
\hline & $\mathrm{pH}$ & $\mathrm{EC}$ & Sulphate & Hardness & $\mathrm{Cu}$ & $\mathrm{Zn}$ & $\mathrm{Cd}$ & $\mathrm{Pb}$ & \multicolumn{2}{|c|}{ Fe Richness } \\
\hline $\mathrm{pH}$ & 1.0 & & & & & & & & & \\
\hline $\mathrm{EC}$ & -0.38 & 1.0 & & & & & & & & \\
\hline Sulphate & -0.42 & 0.94 & 1.0 & & & & & & & \\
\hline Hardness & -0.22 & 0.86 & 0.83 & 1.0 & & & & & & \\
\hline $\mathrm{Cu}$ & -0.82 & 0.27 & 0.28 & 0.18 & 1.0 & & & & & \\
\hline $\mathrm{Zn}$ & -0.74 & 0.62 & 0.56 & 0.51 & 0.83 & 1.0 & & & & \\
\hline $\mathrm{Cd}$ & -0.72 & 0.50 & 0.52 & 0.44 & 0.80 & 0.91 & 1.0 & & & \\
\hline $\mathrm{Pb}$ & -0.67 & 0.30 & 0.33 & 0.32 & 0.85 & 0.80 & 0.89 & 1.0 & & \\
\hline $\mathrm{Fe}$ & 0.03 & 0.39 & 0.23 & 0.39 & -0.15 & 0.17 & -0.06 & -0.14 & 1.0 & \\
\hline Richness & 0.68 & -0.05 & -0.09 & 0.01 & -0.59 & -0.40 & -0.34 & -0.44 & 0.22 & 1.0 \\
\hline
\end{tabular}


TABLE 4

Vascular flora of high-alpine meadows at YLNS in the Andes of central Chile. L, La Lata; C, Chorrillos del Plomo; P, Piedra Carvajal meadow

Flora vascular de las vegas altoandinas del SNYL en los Andes de Chile central. L, vega de La Lata; C, vega de Chorrillos del Plomo; P, vega de Piedra Carvajal

\begin{tabular}{|c|c|c|c|c|}
\hline Scientific name & Family & Life form & Origen & Meadow \\
\hline Acaena magellanica & Rosaceae & Hemicriptophyte & Native & $\mathrm{C}$ \\
\hline Arenaria rivularis & Caryophyllaceae & Hemicriptophyte & Native & $\mathrm{L}$ \\
\hline Calandrinia affinis & Portulacaceae & Hemicriptophyte & Native & $\mathrm{L}$ \\
\hline Calceolaria biflora & Scrophulariaceae & Hemicriptophyte & Native & $\mathrm{L}$ \\
\hline Carex atropicta & Cyperaceae & Hemicriptophyte & Native & $\mathrm{C}, \mathrm{P}$ \\
\hline Carex macloviana & Cyperaceae & Hemicriptophyte & Native & $\mathrm{L}, \mathrm{C}, \mathrm{P}$ \\
\hline Cerastium arvense & Caryophyllaceae & Hemicriptophyte & Exotic & $\mathrm{L}, \mathrm{C}, \mathrm{P}$ \\
\hline Colobanthus quitensis & Caryophyllaceae & Hemicriptophyte & Native & $\mathrm{L}, \mathrm{C}$ \\
\hline Deschampsia venustula & Poaceae & Hemicriptophyte & Native & $\mathrm{L}, \mathrm{P}$ \\
\hline Calamagrostis chrysostachya & Poaceae & Hemicriptophyte & Native & $\mathrm{C}$ \\
\hline Calamagrostis velutina & Poaceae & Hemicriptophyte & Native & $\mathrm{P}$ \\
\hline Draba gilliesii & Brassicaceae & Hemicriptophyte & Native & $\mathrm{C}$ \\
\hline Eleocharis albibracteata & Juncaceae & Hemicriptophyte & Native & $\mathrm{C}, \mathrm{P}$ \\
\hline Empetrum rubrum & Empetraceae & Nanophanerophyte & Native & $\mathrm{C}$ \\
\hline Erigeron andicola & Asteraceae & Hemicriptophyte & Native & $\mathrm{L}, \mathrm{C}, \mathrm{P}$ \\
\hline Erigeron sp. & Asteraceae & Hemicriptophyte & Native & $\mathrm{C}$ \\
\hline Festuca magellanica & Poaceae & Hemicriptophyte & Native & $\mathrm{C}, \mathrm{P}$ \\
\hline Festuca purpurascens & Poaceae & Hemicriptophyte & Native & $\mathrm{L}, \mathrm{C}, \mathrm{P}$ \\
\hline Gaultheria caespitosa ${ }^{I}$ & Ericaceae & Nanophanerophyte & Native & $\mathrm{C}, \mathrm{P}$ \\
\hline Gentiana prostrata & Gentianaceae & Therophyte & Native & $\mathrm{C}, \mathrm{P}$ \\
\hline Hypochaeris thrincioides & Asteraceae & Hemicriptophyte & Endemic & $\mathrm{L}, \mathrm{C}, \mathrm{P}$ \\
\hline Hypsela reniformis & Campanulaceae & Hemicriptophyte & Native & $\mathrm{L}$ \\
\hline Juncus stipulatus & Juncaceae & Hemicriptophyte & Native & $\mathrm{L}$ \\
\hline Patosia clandestina & Juncaceae & Hemicriptophyte & Native & $\mathrm{C}, \mathrm{P}$ \\
\hline Phleum alpinum & Poaceae & Hemicriptophyte & Exotic & $\mathrm{P}$ \\
\hline Plantago barbata & Plantaginaceae & Hemicriptophyte & Native & $\mathrm{L}, \mathrm{C}, \mathrm{P}$ \\
\hline Poacea sp. & Poaceae & Hemicriptophyte & & $\mathrm{P}$ \\
\hline Trifolium polymorphum & Fabaceae & Hemicriptophyte & Native & $\mathrm{L}$ \\
\hline Werneria pygmea & Asteraceae & Hemicriptophyte & Native & $\mathrm{L}, \mathrm{C}, \mathrm{P}$ \\
\hline Lemna sp. ${ }^{1}$ & Lemnaceae & Hydrofita flotante & & $\mathrm{L}$ \\
\hline Mimulus glabratus & Scrophulariaceae & Therophyte & Native & $\mathrm{L}$ \\
\hline Stuckenia filiformis ${ }^{1}$ & Potamogetonaceae & Hemicriptophyte & Native & $\mathrm{P}$ \\
\hline
\end{tabular}

${ }^{1}$ New records for the area and for central Chile. Nuevos registros para el área y para Chile central

TABLE 5

General characteristic of the flora present in the high-alpine meadows at YLNS, central Chile Características generales de la flora presente en las vegas altoandinas del SNYL, en Chile central

\begin{tabular}{lccc}
\hline & Piedra Carvajal & Chorrillos del Plomo & La Lata \\
\hline Surface $\left(\mathrm{m}^{2}\right)$ & 26,180 & 5,755 & 18,190 \\
Total cover $(\%)$ & 87.8 & 75.6 & 52.4 \\
Richness & 14 & 18 & 16 \\
Unique species & 3 & 6 & 8 \\
Shared species & 3 & & \\
\hline
\end{tabular}


in all three meadows. Group II is only represented at Chorrillos del Plomo meadow from 3,242 to $3,270 \mathrm{~m}$ of altitude while group III is found in all three meadows from 2,799 to $3,293 \mathrm{~m}$ of altitude. Dominant (cover $>26 \%$ ), secondary (cover $<25 \%$ ) and rare species (cover $<5 \%$ ) characteristics of these plant formations are listed in Table 6. Besides these groups, some aquatic plant species dominates small lagoons present in Piedra Carvajal and La Lata meadows, such as Juncus stipulatus, Lemna sp. and Stuckenia filiformis (Pers.) Börner (ex Potamogeton strictus Phil.); micro algae are also quite common in these lagoons.

Group I corresponds to a well defined highdiversity plant formation (26 species) that is dominated by Patosia clandestina, Erigeron andicola, Festuca magellanica, Plantago barbata, Carex macloviana and Wermeria pygmea, with a diverse group of secondary species. This plant formation is present in all study meadows in areas where water quality is close to dilute waters described for streams in the Andes of central Chile (i.e., neutral, low hardness and EC, and low in minerals). However, it shows some differences among meadows; it is very common at Piedra Carvajal where it grows as continuous grassland, reaching up to $75 \%$ of total cover but it is restricted to very small high-slope patches at Chorrillos del Plomo meadow. In this last meadow, secondary species change and two new species occur, Gaultheria caespitosa and Empetrum rubrum. Both species have not been previously described in high-alpine meadows of central Chile. This plant formation reaches up to $60 \%$ total cover in La Lata meadow but as patches with lower plant height than in Piedra Carvajal meadow (4-cm height versus $8-\mathrm{cm}$ height, respectively). This may be the result of higher cattle impact at $\mathrm{La}$ Lata than in Piedra Carvajal meadow during the spring-summer periods.

Group II is a plant formation with 14 different plant species (half the species number of group I); it is dominated by Calamagrostis chrysostachya (ex Deyeuxia chrysostachya), Carex atropicta and C. macloviana (Table 6) with three main secondary species (Werneria pigmea, Hypochaeris thrincioides, and Cerastium arvense) and eight less represented species. This plant formation is only represented at Chorrillos del Plomo meadow where it dominates. It has high cover values (46 to 100
$\%)$ and reaches up to $17 \mathrm{~cm}$ height. According to the soil humidity level, $C$. atropicata (dominant in low water content areas) is replaced by $C$. macloviana (dominant in humid areas) as a secondary species. This plant formation seems to be associated with slightly acidic to acidic waters, having both high hardness (i.e., Ca levels) and levels of sulphate but low mineral contents (i.e., total dissolved $\mathrm{Cu}$ and $\mathrm{Fe}$ ).

\section{TABLE 6}

Plant formations (groups) according to the phytosociological classification analysis of the high-alpine meadows at YLNS, Andes of central Chile. Numbers indicate plant covers; $1,1-20 \%$; 2, 21-40\%; 3, 41-60\%; 4, 61-80\%; 5, 81-100\%

Formaciones vegetales (grupos) de acuerdo al análisis de clasificación fitosociológica de las vegas altoandinas del SNYL, en Chile central. Los números indican la cobertura vegetal; $1,1-20 \% ; 2,21-40 \% ; 3,41-60 \% ; 4,61-80 \% ; 5$. $81-100 \%$

\begin{tabular}{|c|c|c|c|}
\hline \multirow[t]{2}{*}{ Species } & \multicolumn{3}{|c|}{ Group } \\
\hline & I & II & III \\
\hline Acaena magellanica & 1 & & . \\
\hline Calamagrostis velutina & 1 & . & . \\
\hline Gentiana prostrata & 1 & . & . \\
\hline Poacea sp. & 1 & . & . \\
\hline Trifolium polymorphum & 1 & . & . \\
\hline Calandrinia affinis & 1 & . & . \\
\hline Calceolaria bifolia & 1 & . & . \\
\hline Phleum alpinum & 1 & . & . \\
\hline Hypsela reniformis & 1 & . & . \\
\hline Empetrum rubrum & 1 & . & . \\
\hline Gaultheria caespitosa & 2 & . & . \\
\hline Patosia clandestina & 3 & . & . \\
\hline Plantago barbata & 4 & . & . \\
\hline Erigeron andicola & 4 & . & . \\
\hline Werneria pygmea & 5 & 2 & . \\
\hline Carex atropicta & 1 & 3 & . \\
\hline Festuca magellanica & 3 & 1 & . \\
\hline Hypochaeris thrincioides & 2 & 2 & . \\
\hline Eleocharis albibracteata & 1 & 1 & . \\
\hline Sphagnum sp. & 1 & 1 & . \\
\hline Bryophyta & 3 & 2 & 2 \\
\hline Cerastium arvense & 1 & 2 & 2 \\
\hline Carex macloviana & 3 & 3 & 4 \\
\hline Festuca purpurascens & 2 & 1 & 5 \\
\hline Colobanthus quitensis & . & 1 & 1 \\
\hline Calamagrostis chrysostachya & . & 5 & . \\
\hline Draba gilliesii & . & 1 & . \\
\hline Erigeron sp. & . & 1 & . \\
\hline Juncus stipulatus & 1 & . & 1 \\
\hline Deschampsia venustula & 1 & . & 1 \\
\hline Arenaria rivularis & . & . & 1 \\
\hline Total number of species & 26 & 14 & 8 \\
\hline Number of sampling points & 11 & 6 & 8 \\
\hline
\end{tabular}


Group III corresponds to a very low diversity plant formation (eight species) that reaches up to $30-40 \mathrm{~cm}$ height (Table 6). Its total cover varies from 32 to $99 \%$, but it dominates the areas where very acidic blue or milky coloured waters flows in all study meadows. Dominant species are Festuca purpurascens and Carex macloviana with only two important secondary species (Cerastium arvense and a bryophyte).

\section{Plant species and water quality relationships}

There are few significant correlations among water chemistry factors and plant species richness (Table 3). The $\mathrm{pH}$ of water was significantly and positively correlated to plant species richness of sampling sites while both total dissolved $\mathrm{Cu}$ and $\mathrm{Pb}$ were significantly and negatively correlated to plant species richness. Acidification and metal-enrichment of waters result in a marked reduction on the species number. Indeed, acidic and $\mathrm{Cu}$-rich waters were dominated by few species, such as Festuca purpurascens and Colobanthus quitensis.

Investigations on relationships among metal contents in waters and metal content in aerial plant tissues from field collected plants show significant and positive correlations among both $\mathrm{Cu}$ and $\mathrm{Zn}$ contents in shoots and total dissolved levels of these metals in water $\left(\mathrm{r}_{\mathrm{s}}=\right.$ 0.86 and $\mathrm{P}<0.01$ for $\mathrm{Cu} ; \mathrm{r}_{\mathrm{s}}=0.62$ and $\mathrm{P}<0.05$ for $\mathrm{Zn}$ ) (Table 7). It is interesting to note the

TABLE 7

Metal content in shoots of plant species growing in sites with different water qualities of high-alpine meadows at YLNS

Contenido de metales en los vástagos de especies vegetales creciendo en sitios con distintas calidades de agua en las vegas altoandinas del SNYL

\begin{tabular}{|c|c|c|c|c|c|c|c|c|c|}
\hline \multirow[t]{3}{*}{ Species } & \multirow[t]{3}{*}{ Meadow } & \multirow[t]{3}{*}{ Site } & \multicolumn{3}{|c|}{ Metal in shoot } & \multicolumn{4}{|c|}{ Water chemistry } \\
\hline & & & \multirow[t]{2}{*}{$\begin{array}{c}\mathrm{Cu} \\
\left(\mathrm{mg} \mathrm{kg}^{-1}\right)\end{array}$} & \multirow[t]{2}{*}{$\begin{array}{c}\mathrm{Zn} \\
\left(\mathrm{mg} \mathrm{kg}^{-1}\right)\end{array}$} & \multirow[t]{2}{*}{$\begin{array}{c}\mathrm{Fe} \\
\left(\mathrm{mg} \mathrm{kg}^{-1}\right)\end{array}$} & \multicolumn{3}{|c|}{$\begin{array}{l}\text { Total disolved } \\
\text { metal }\left(\mu \mathrm{g} \mathrm{L}^{-1}\right)\end{array}$} & \multirow[t]{2}{*}{$\mathrm{pH}$} \\
\hline & & & & & & $\overline{\mathrm{Cu}}$ & $\mathrm{Zn}$ & $\mathrm{Fe}$ & \\
\hline \multirow[t]{12}{*}{ Festuca purpurascens } & Piedra Carvaja & 1 & 1026 & 43 & & & & & \\
\hline & & 2 & 348 & 57 & & & & & \\
\hline & & 3 & 286 & 34 & & & & & \\
\hline & & 4 & 282 & 70 & 144 & 1120 & 78 & 8 & 5.33 \\
\hline & & 5 & 131 & 27 & & & & & \\
\hline & & 6 & 62 & 48 & & & & & \\
\hline & La Lata & 1 & 324 & 72 & 610 & 6143 & 337 & 22 & 4.96 \\
\hline & & 2 & 299 & 122 & 132 & 5959 & 328 & 19 & 5.13 \\
\hline & & 3 & 145 & 47 & 1103 & 34 & 20 & 12 & 7.97 \\
\hline & & 4 & 78 & 28 & 257 & 2410 & 97 & 10 & 5.76 \\
\hline & & 5 & 45 & 34 & 422 & 754 & 76 & 73 & 4.66 \\
\hline & Chorrillos del Plomo & 1 & 14 & 188 & 111 & 33 & 118 & 38 & 5.65 \\
\hline \multirow[t]{2}{*}{ Calamagrostis chrysostachya } & Chorillos del Plomo & 1 & 20 & 54 & 191 & & & & \\
\hline & & 2 & 17 & 54 & 137 & 33 & 118 & 38 & 5.65 \\
\hline \multirow[t]{2}{*}{ Carex macloviana } & La Lata & 1 & 487 & 88 & 312 & 2410 & 97 & 10 & 5.76 \\
\hline & Piedra Carvajal & 1 & 181 & 58 & 553 & 446 & 34 & 16 & 6.20 \\
\hline \multirow[t]{2}{*}{ Gaultheria caespitosa } & Chorrillos del Plomo & 1 & 31 & 54 & 439 & & & & 5.82 \\
\hline & Piedra Carvajal & 1 & 18 & 88 & 226 & & & & \\
\hline Juncus stipulatus & La Lata & 1 & 69 & 70 & 1,146 & 10 & 7 & 31 & 8.27 \\
\hline Empetrum rubrum & Chorrillos del Plomo & 1 & 38 & 52 & 390 & & & & 5.70 \\
\hline Deschampsia venustula & Piedra Carvajal & 1 & 32 & 42 & 236 & 11 & 18 & 34 & 6.67 \\
\hline Werneria pygmea & Piedra Carvajal & 1 & 13 & 43 & 97 & 5 & 3 & 14 & 9.56 \\
\hline \multirow[t]{2}{*}{ Briophyte } & La Lata & 1 & 2,731 & 375 & 3,054 & 5,959 & 328 & 19 & 5.13 \\
\hline & & 2 & 6,034 & 259 & 2,270 & 6,006 & 328 & 19 & 5.08 \\
\hline
\end{tabular}


very high total $\mathrm{Cu}$ contents $(2,731$ to $6,034 \mathrm{mg}$ $\mathrm{kg}^{-1}$ dry weight, $\mathrm{dw}$ ) detected on aerial tissues of a moss species (Briophyte) that thrives on $\mathrm{Cu}$-rich (approximately 6,000 $\mu \mathrm{g} \mathrm{L}^{-1}$ ) and acidic (approximately 5.0) waters at La Lata meadow (Table 7). Furthermore, Festuca purpurascens plants are able to thrive along a broad water quality gradient in terms of $\mathrm{pH}$ (4.7 to 7.9) and total dissolved $\mathrm{Cu}$ (34 to 6,143 $\mu \mathrm{g} \mathrm{L} \mathrm{L}^{-1}$; Table 7$)$, thus determining a broad range of $\mathrm{Cu}$ content in shoots (45 to $1,026 \mathrm{mg}$ $\mathrm{kg}^{-1} \mathrm{dw}$ ). Laboratory results of $\mathrm{Cu}$ tolerance testing of $F$. purpurascens seedlings grown from seeds collected in four sites with different water qualities indicate that all tested individuals of this species are tolerant to $\mathrm{Cu}$, irrespective of the water quality of the site of provenance of the seeds (i.e., low or high in total dissolved $\mathrm{Cu}$; Tables 1 and 8 ), as root elongation of seedling of all sampling sites is not significantly inhibited by increasing $\mathrm{Cu}$ concentrations of testing solutions (Table 8).

CCA among plant species abundance and selected water quality variables $(\mathrm{pH}$, sulphate, total dissolved $\mathrm{Cu}$, and total dissolved $\mathrm{Fe}$ ) indicates that the first axis (eigenvalue, $\lambda=$ 0.62 ) is the most important for explaining overall variation of species abundance-water quality relation (56.4\%, Table 9 ). This axis is strongly related to total dissolved $\mathrm{Cu}$ (inter-set correlation $=0.877$, Table 10). However, the global Monte Carlo permutation test shows that

TABLE 8

Copper tolerance testing of Festuca purpurascens plants belonging to sites with different water qualities at the high-alpine meadows of the YLNS. The mean and standard deviation are given

Ensayos de tolerancia a cobre en plantas de of Festuca purpurascens colectadas en sitios con distintas calidades de agua en las vegas altoandinas del SNYL

\begin{tabular}{|c|c|c|c|c|}
\hline \multirow[t]{2}{*}{$\overline{\mathrm{Cu} \text { added (nominal) }}$} & \multirow[b]{2}{*}{$\begin{array}{c}\text { La Lata } \\
\text { Clear waters (V37) }\end{array}$} & \multicolumn{2}{|c|}{ Root elongation $(\mathrm{cm})$} & \multirow[b]{2}{*}{$\begin{array}{c}\text { Piedra Carvajal } \\
\text { Acidic/Cu-Rich } \\
\text { waters(K17) }\end{array}$} \\
\hline & & $\begin{array}{c}\text { La Lata } \\
\text { Mine spoil(U5) }\end{array}$ & $\begin{array}{c}\text { La Lata } \\
\text { Milky waters(L33) }\end{array}$ & \\
\hline $0.0 \mathrm{mg} \mathrm{L}^{-1}$ & $1.1 \pm 0.80$ & $1.4 \pm 0.31$ & $1.8 \pm 0.66$ & $2.2 \pm 0.49$ \\
\hline $0.125 \mathrm{mg} \mathrm{L}^{-1}$ & $1.4 \pm 0.74$ & $1.2 \pm 0.22$ & $1.6 \pm 0.54$ & $2.0 \pm 0.61$ \\
\hline $0.25 \mathrm{mg} \mathrm{L}^{-1}$ & $1.1 \pm 0.59$ & $1.7 \pm 0.78$ & $2.0 \pm 0.69$ & $2.4 \pm 0.56$ \\
\hline $0.5 \mathrm{mg} \mathrm{L}^{-1}$ & $1.9 \pm 0.55$ & $1.4 \pm 0.33$ & $2.0 \pm 0.54$ & $2.2 \pm 0.48$ \\
\hline \multirow[t]{2}{*}{$1.0 \mathrm{mg} \mathrm{L}^{-1}$} & $0.8 \pm 0.71$ & $1.7 \pm 1.02$ & $2.2 \pm 0.65$ & $2.1 \pm 1.01$ \\
\hline & \multicolumn{4}{|c|}{ Kruskal-Wallis ANOVA by ranks } \\
\hline $\mathrm{H}$ & 6.2 & 10.9 & 8.3 & 2.1 \\
\hline $\mathrm{df}$ & 4 & 4 & 4 & 4 \\
\hline $\mathrm{N}$ & 27 & 89 & 89 & 58 \\
\hline $\mathrm{P}$ & 0.183 & 0.065 & 0.08 & 0.716 \\
\hline
\end{tabular}

TABLE 9

Summary of CCA (first four axes) of the species abundance - water quality variables

Resumen del CCA (primeros cuatro ejes) para las variables de abundancia específicas y calidad del agua

\begin{tabular}{lcccc}
\hline Axes & 1 & 2 & 3 & 4 \\
\hline Eigenvalue $(\lambda)$ & 0.627 & 0.310 & 0.145 & 0.029 \\
Species-water quality correlations & 0.921 & 0.891 & 0.647 & 0.453 \\
Cumulative percentage of variance $(\%):$ & & & 33.3 & 34.2 \\
(a) species & 19.3 & 28.8 & 97.4 & 100.0 \\
(b) species-water quality relation & 56.4 & 84.3 & & \\
\hline
\end{tabular}


both the first canonical axis $(\mathrm{F}-$ ratio $=1.91, \mathrm{P}=$ 0.24 ) and all canonical axes (F-ratio $=1.21, \mathrm{P}=$ $0.36)$ are not significant. This could have been the result of the small number of sampling sites were both water chemistry and plants factors were available for the analysis $(\mathrm{n}=13)$. Therefore, no significant relationship among plant species abundance and all four water chemistry variables considered in the analysis was found. The forward-selection procedure to determine the contribution of each water quality parameter to the ordination model indicates that total dissolved $\mathrm{Cu}$ is the water quality variable that has a significant contribution $($ F-ratio $=2.4, \mathrm{P}=0.002)$ to variation of species abundance, according to an unrestricted partial Monte Carlo permutation test (Table 11). Therefore, a second CCA was performed among plant species abundance and total dissolved $\mathrm{Cu}$ in water.

Results of the new CCA indicate that the canonical eigenvalue of the first canonical axis is high $(\lambda=0.58)$, explaining $17.9 \%$ of the overall variation of species abundance-water quality relation; the Monte Carlo permutation test shows that all canonical axis are significant $($ F-ratio $=2.39, \mathrm{P}=0.002)$. Total dissolved $\mathrm{Cu}$ concentration in water is strongly related to the first canonical axis (inter-set correlation = 0.896; Table 12), thus explaining most of the variation of plant species abundance. Plot of the first two axes from CCA ordination is shown in Fig. 2; the first axis (constrained) represents the variation of species abundance that is explained by total dissolved $\mathrm{Cu}$ concentration in water while the second axis (unconstrained) represents residual variation that is not explained by total dissolved $\mathrm{Cu}$. Relative location among plant species (solid triangles) and sampling sites (solid circles) in the CCA ordination diagram indicates the sites where plant species show highest relative cover (Fig. 2). Position of the species in the diagram is in agreement with sampling sites. The arrow in the diagram represents the gradient of total dissolved $\mathrm{Cu}$ and its relative location indicates

TABLE 10

Canonical coefficients and the inter-set correlations (correlation coefficients) of water chemistry variables with the first two axes of the CCA

Coeficientes de correlación canonical y correlaciones inter-ser (coeficientes de correlación) de las variables de la química del agua con los primeros dos ejes del ACC

\begin{tabular}{lcccc}
\hline Axis-variable & \multicolumn{2}{c}{ Canonical coefficients } & Correlation coefficients \\
\hline & 1 & 2 & 1 & 2 \\
$\mathrm{pH}$ & 0.1795 & -0.8125 & -0.5579 & -0.4773 \\
Sulphate & -0.1382 & 0.8701 & 0.2392 & 0.7484 \\
$\ln \mathrm{Cu}$ & 1.1425 & -0.8048 & 0.8772 & 0.1758 \\
$\ln \mathrm{Fe}$ & -0.2139 & -0.1734 & -0.2569 & 0.0551 \\
\hline
\end{tabular}

TABLE 11

Marginal $(\lambda 1)$ and conditional effects $(\lambda$ A) obtained from forward selection procedure. Significance was confirmed by unrestricted partial Monte Carlo permutation test

Efectos marginales y condicionales de los procedimientos de selección creciente. La significancia fue confirmada con el test no restringido y parcial de permutación de Monte Carlo

\begin{tabular}{lllll}
\hline Water chemistry variables & $\lambda 1$ & $\lambda$ A & P-value & F-value \\
\hline $\ln \mathrm{Cu}$ & 0.58 & 0.58 & 0.002 & 2.40 \\
$\mathrm{pH}$ & 0.37 & 0.32 & 0.230 & 1.33 \\
Sulphate & 0.33 & 0.20 & 0.602 & 0.83 \\
$\ln \mathrm{Fe}$ & 0.08 & 0.07 & 0.940 & 0.28 \\
\hline
\end{tabular}


the relationship with plant abundance and sampling points. The length of the arrow indicates the importance of the water chemistry factor and the perpendicular projection of solid triangles on the arrow indicates the species distribution in the total dissolved $\mathrm{Cu}$ gradient. In the first axis of the CCA diagram the species follow a total dissolved $\mathrm{Cu}$ gradient that increases from left to right of the diagram (i.e. low to high total dissolved $\mathrm{Cu}$ concentration in waters). For instance, Festuca purpurascens, Colobanthus quitensis, and Arenaria rivularia are more abundant in habitats with high concentrations of total dissolved $\mathrm{Cu}$ while Erigeron andicola, Festuca magellanica, Patosia clandestina, Werneria pygmea, and Plantago barbata are more abundant in habitats with low concentrations of total dissolved $\mathrm{Cu}$ (Fig. 2).

\section{DISCUSSION}

Marked surface water chemistry gradients have been created in the mountain valley of the YLNS from different origins; natural from oxidative processes of high-altitude $\mathrm{Cu}-\mathrm{Mo}$ deposits (acid rock drainage, ARD), and anthropogenic from acid mine drainage (AMD) resulting from an abandoned pile of mine wastes left by historic silver exploitations located nearby La Lata meadow. Snow melting during spring/summer months followed by water percolation through permeable mineral deposits and dumped mine wastes result in oxidation and hydrolysis processes that leads to surface water acidification, increased salinity, and mineral enrichment. Indeed, it is well documented that mineral deposits and massive mine wastes rich in metal sulphurs (i.e., pyrite, $\mathrm{FeS}_{2}$ ) generate ARD or AMD when exposed to air and water (Ritcey 1989, Gray 1996, Gray 1998, Kontopoulos 1998, Benner et al. 1999, Peppas et al. 2000, Dinelli et al. 2001, Evangelou 2001) as pyrite weathers relatively rapid (Clow \& Sueker 2000).

In most cases, alpine meadows at YLNS receive water from more than one source (i.e. ground-water from one or several slopes and surface water from streams), so environmental heterogeneity in water quality is high, both among and inside meadows. For example, waters among meadows varied in terms of $\mathrm{pH}$ (mean values) in the following order of increasing acidity, Piedra Carvajal (7.6) $<\mathrm{La}$ Lata (6.4) < Chorrillos del Plomo (5.6), but high $\mathrm{pH}$ variability exists inside each meadow: two units in Chorrillos del Plomo and 4-5 units in the other two meadows. On the other hand, surface waters followed the following order in terms of increasing total dissolved $\mathrm{Cu}$ levels (mean values), Chorrillos del Plomo (41 $\left.\mu \mathrm{g} \mathrm{L}^{-1}\right)<$ Piedra Carvajal $\left(476 \mu \mathrm{g} \mathrm{L}^{-1}\right)<\mathrm{La}$ Lata $\left(2,579 \mu \mathrm{g} \mathrm{L}^{-1}\right)$. Again, high variability exists for this parameter inside each meadow: three times at Chorrillos del Plomo and from 600 to almost 2,000 times in the other two meadows.

Increased levels of metals, changes in $\mathrm{pH}$ from acidic to alkaline, marked changes in hardness, electric conductivity and sulphate levels seems to be common on streams at high elevation as shown by preliminary studies performed by this group and scarce published information (Cepeda \& Morales 2006). Furthermore, information available in literature indicates that ARD is a natural phenomenon that has occurred in the longitudinal belt of porphyry $\mathrm{Cu}-\mathrm{Mo}$ deposits along the northcentral Andes $\left(32-34^{\circ} \mathrm{S}, 70^{\circ} \mathrm{W}\right)$ called Río Blanco-Los Bronces-El Teniente (Arias \& Cruzat 1974, Henríquez 1974, Barceló 1984), a

TABLE 12

Canonical coefficients and the inter-set correlations (correlation coefficients) of water chemistry variables with the first two axes of the CCA

Coeficientes de correlación canonical y correlaciones inter-ser (coeficientes de correlación) de las variables de la química del agua con los primeros dos ejes del ACC

\begin{tabular}{|c|c|c|c|c|}
\hline Axis-variable & Canonical coefficients & \multicolumn{3}{|c|}{ Correlation coefficients } \\
\hline & 1 & 2 & 1 & 2 \\
\hline $\ln \mathrm{Cu}$ & 1 & 0 & 0.8958 & 0 \\
\hline
\end{tabular}


phenomenon that can be magnified by current and future mine operations (Dold \& Fontboté 2001). Therefore, broad environmental gradients on hydrochemistry at high alpine areas of the Andes in north-central Chile may be a more common phenomenon than previously considered. However, this phenomenon has not been systematically evaluated yet.

Relation among water quality and high-Alpine meadow vegetation

Our data suggests that environmental gradients in surface water, such as $\mathrm{pH}$ and total dissolved
$\mathrm{Cu}$, are important factors determining plant distribution, diversity and abundance in highalpine meadows at YLNS. Large (mean values) and small (variability values) scale variations in water quality parameters may explain changes in plant community structure among and inside alpine meadows. On one hand, we have found quite even plant diversities (14 to 18) among study meadows, which are in the range of six to 19 species described for alpine meadows in the Andes of South America (Squeo et al. 1994, Teillier 2005). However, this is an unexpected result from the viewpoint of the species-area relationship (Begon et al. 1990) as study meadows have marked

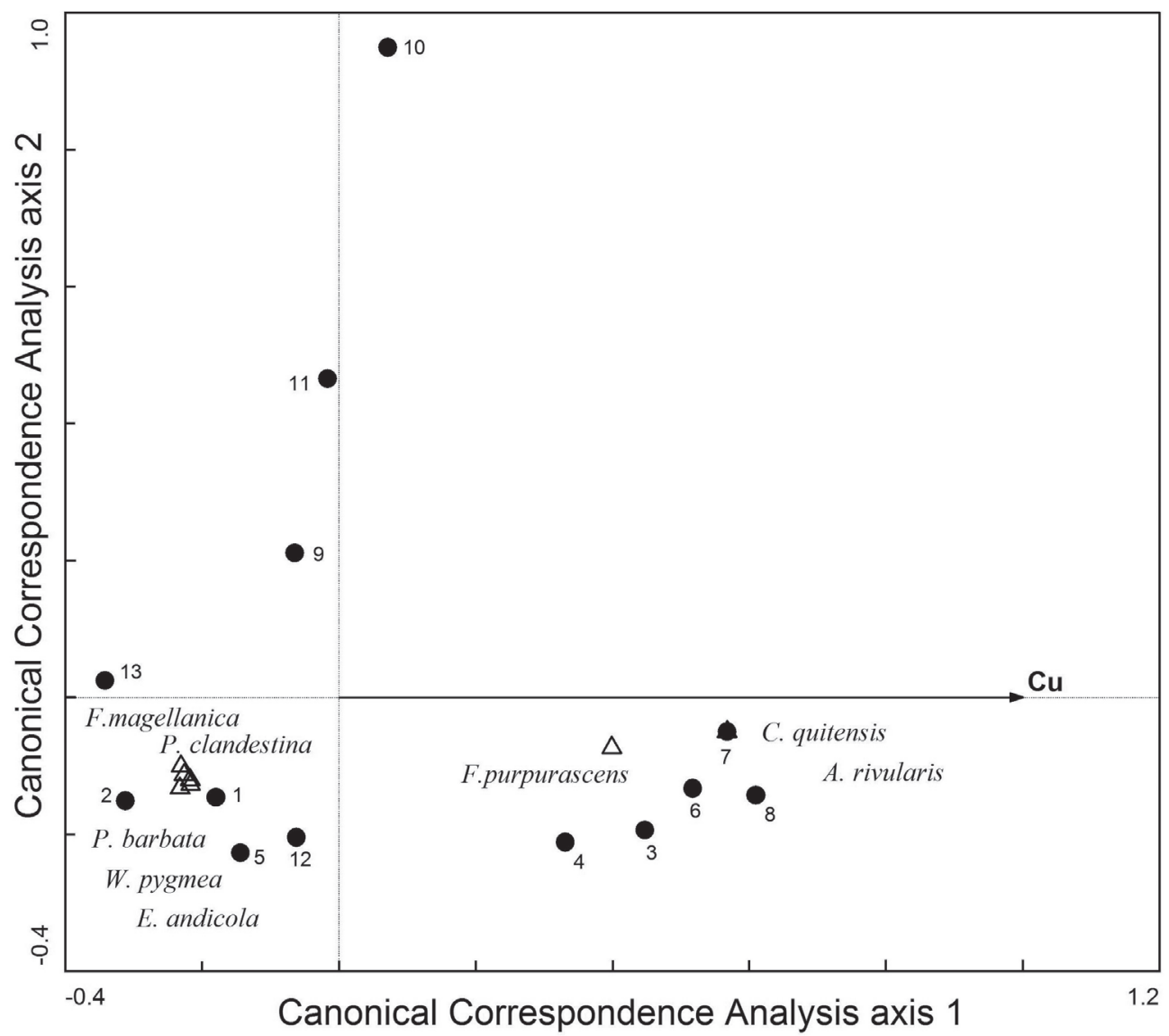

Fig. 2: Canonical ordination diagram illustrating the distribution of water chemistry factors (arrows, $\mathrm{n}=1$ ), sampling sites (solid circles, $\mathrm{n}=13$ ) and plant species (solid triangles, $\mathrm{n}=8$ ) in ordination space. Water chemistry factor correspond to total dissolved $\mathrm{Cu}$. Only the species well related to the first ordination axis are included (17\% of minimal adjust).

Diagrama de ordenación canónico que ilustra la distribución de los factores químicos del agua (flechas, $\mathrm{n}=1$ ), las unidades de muestreo (círculos sólidos, $\mathrm{n}=13$ ) y las especies vegetales (triángulos sólidos; $\mathrm{n}=8$ ) en el espacio de ordenación. El factor químico del agua corresponde al $\mathrm{Cu}$ total disuelto. Se incluyen sólo las especies bien relacionadas con el primer eje de ordenación (ajuste mínimo al $17 \%$ ). 
differences in size $\left(5,755\right.$ to $\left.26,180 \mathrm{~m}^{2}\right)$. A possible explanation for this finding may be the occurrence of high environmental variability at small spatial scales, particularly in the small meadow (Chorrillos del Plomo) as it has previously suggested (Stewart et al. 2000, Wilson 2000). Indeed, Chorrillos del Plomo meadow showed the highest diversity in terms of both species diversity and plant associations. Besides the high variability in surface water quality found in this study, Chorrillos del Plomo meadow could have more marked gradients in soil moisture and salinity due to its higher slope and complex microtopography. Therefore, a number of environmental factors may be involved in structuring high-alpine meadow communities, surface water quality being another one not well considered until now.

On the other hand, Chorrillos del Plomo meadow has, in general, more acidic waters with higher contents of sulphate but low contents of metals than La Lata and Piedra Carvajal meadows. The last two meadows have neutral to slightly acid waters, low in sulphate but high in metal contents. This general difference (mean values) may explain changes in dominant plant formations found among study meadows. Chorrillos del Plomo meadow has a unique plant formation (group II according to the phytosociological classification), dominated by Calamagrostis chrysostachya (ex Deyeuxia chrysostachya), Carex atropicta and C. macloviana with few secondary species. The other two plant formations (group I and III), are less represented in areas with different water qualities. La Lata and Piedra Carvajal meadows share similar water qualities, with well represented areas with either dilute waters or AMD/ARD impacted waters. On these areas, two different plant formations dominate. Plant formation defined as group 1, with high diversity (26 species) and dominated by Patosia clandestina, is common in dilute waters (low contents of sulphate and metals), while plant formation defined as group III, with very low diversity (eight species) and dominated by Festuca purpurascens, is common in areas where very acidic and high metal content waters flows. Squeo et al. (1999) has described two main plant formations for the high-alpine meadows of the Andes in north- central Chile; grass-dominated meadows (i.e., Deschampsia caespitose, Deyeuxia velutina), such as group II and III in this study, and juncaceae cushion-like dominated meadows (i.e., Patosia clandestine, Oxychloe andina), such as group I in this study. This second vegetation type has been described by other authors as Patosia clandestina-Juncus balticus formation and it is considered as the representative vegetation of alpine meadows in north-central Chile (Gajardo 1994, Luebert \& Pliscoff 2006). It will be interesting to further evaluate if this two general vegetation types of the high-alpine meadows may be considered as indicative of specific water qualities.

Spatial variation in $\mathrm{pH}$ and metal levels (i.e., total dissolved $\mathrm{Cu}$ ) in surface waters would select for tolerant species in those particular areas having acidic and metal-rich waters, as these factors can limit plant establishment and growth. For example, copper and zinc are essential micronutrients for all organisms, but it is well know that they are toxic at high concentrations (Baker \& Walker 1989, Fernándes \& Henríques 1991, Adriano 2001). Levels of total dissolved $\mathrm{Cu}$ and $\mathrm{Zn}$ found in this study were in most cases well above the acute quality criteria for aquatic life recommended by United States EPA (calculated value of $16.5 \mu \mathrm{g} \mathrm{L^{-1 }}$ for $\mathrm{Cu}$ in pristine waters of north-central Chile according to Villavicencio et al. (2005); $120 \mu \mathrm{g} \mathrm{L}^{-1}$ for $\mathrm{Zn}$ according to United States EPA 1999), and they should be therefore toxic for aquatic organisms and plants. However, organisms differ widely in their tolerance to metals with some organisms being able to store certain metals with no adverse physiological response (Peters et al. 2007). Indeed, some species thriving on highly $\mathrm{Cu}$-rich waters in alpine meadows at YLNS, such as Festuca purpurascens and mosses, did not show metal toxicity symptoms and were able to reproduce on these field conditions even though they reached very high $\mathrm{Cu}$ contents (2,731 to $6,034 \mathrm{mg} \mathrm{kg}^{-1} \mathrm{dw}$ ) on aerial tissues. As a reference, the commonly observed range of $\mathrm{Cu}$ in aerial tissues (dw) of crops and fruit trees varies from 4 to $40 \mathrm{mg}$ $\mathrm{kg}^{-1}$ (Adriano 2001) and from 2.7 to $21 \mathrm{mg} \mathrm{kg}^{-1}$ in aquatic plants (Harrison 1998).

Our results showed that plant richness was significantly reduced by increasing acidity and $\mathrm{Cu}$ content in surface waters and only some 
species were able to growth and reproduce in this stressful condition, such as Festuca purpurascens, Colobanthus quitensis, and Arenaria rivularia. This species were less represented in other areas and they can be defined as indicator plants for water anomalies (i.e., metal-rich waters). On the other hand, species like Carex macloviana, Patosia clandestina, and Erigeron andicola, more abundant in habitats with dilute waters, can be used as indicators of dilute waters. However, further standard dose-response laboratory tests (Ginocchio et al. 2002, Ginocchio \& Baker 2004) are needed to determine the degree of tolerance of these species to $\mathrm{pH}$ and metals. Reduction in grass diversity, density and productivity has been described for other meadows impacted by historic mine exploitations (Stoughton \& Marcus 2000), but development of tolerance to metals in plants has been demonstrated in several studies around the word (Bradshaw 1984, Bradshaw \& Hardwick 1989, Kruckberg \& Wu 1992, Macnair \& Baker 1994, Brooks 1998). Plant adaptation to increased metal levels can occur rapidly, sometimes within few years of disturbance (Bradshaw 1984, Baker 1987, Tyler et al. 1989), therefore, under a long history of interaction, porphyry $\mathrm{Cu}-\mathrm{Mo}$ deposits and historic mine spoils affecting surface water quality at the YLNS may have resulted in directional selection for metal and acidic water tolerant plant species. Indeed, copper tolerance testing of $F$. purpurascens seedlings under laboratory conditions showed the constitutive tolerance of this species to elevated $\mathrm{Cu}$ concentrations. Further research to objectively evaluate degree of tolerance of high-alpine meadow species and populations to metal-rich and acidic waters are, however, required.

This pioneer study suggests the importance of surface water chemistry factors, besides other hydrological factors such as soil humidity and salinity, in determining plant abundance and diversity in high-alpine meadows at the YLNS, the Andes of north-central Chile. However, a need for increasing the sampling effort is needed to be able to get more conclusive results and further studies are needed to verify this phenomenon in other alpine areas of north-central Chile, in order to get more conclusive and general results.

\section{ACKNOWLEDGEMENTS}

The study was funded by FONDECYT 1050130 grant to R. Ginocchio. We would like to thanks the support of Dr. Patricio H. Rodríguez, Centro de Investigación Minera y Metalúrgica (CIMM), the rangers at Yerba Loca Natural Sanctuary (YLNS), particularly Mr. Julio Bruna, and the Director of the Centro Cordillera, Municipalidad de Lo Barnechea, Mr. Pablo Villoch.

\section{LITERATURE CITED}

ADRIANO DC (2001) Trace elements in terrestrial environments. Biogeochemistry, bioavailability, and risks of metals. Springer-Verlag, New York, New York, USA. 866 pp.

ARIAS J \& A CRUZAT (1974) Estudio geoquímico en el área de la mina Río Blanco-Andina, Provincia de Aconcagua. IIG \& Compañía Minera Andina, Santiago, Chile. 27 pp.

ARROYO MTK, C MARTICORENA, O MATTHEI, M MUÑOZ \& P PLISCOFF (2002) Análisis of the contribution and efficiency of the Santuario de la Naturaleza Yerba Loca, $33^{\circ} \mathrm{S}$ in protecting the regional vascular plant flora (Metropolitan and fifth regions of Chile). Revista Chilena de Historia Natural 75: 767-792.

BAKER AJM (1987) Metal tolerance. New Phytologist 106: 93-111.

BAKER AJM \& PL WALKER (1989) Physiological responses of plants to heavy metals and the quantification of tolerance and toxicity. Chemical Specialization and Bioavailability 1: 7-17.

BARCELÓ J (1984) Geología del Santuario de la Naturaleza Yerba Loca, Región Metropolitana, Chile. Corporación Nacional Forestal, Santiago, Chile. 38 pp

BASSI HGL (1982) Geología y potencialidad minera del distrito cuprífero Bronces-Yerba Loca, Provincia de Santiago, Chile. Quinto Congreso Latinoamericano de Geología, Actas 3: 111-145, Buenos Aires, Argentina.

BEGON M, JL HARPER \& CR TOWNSEND (1990) Ecology: individuals, populations, and communities. Blackwell Scientific Publications, Oxford, United Kingdom. 945 pp.

BENNER SG, DW BLOWES, WD GOULD, RB HERBERT \& CJ PTACEK (1999) Geochemistry of a permeable reactive barrier for metals and acid mine drainage. Environmental Science \& Technology 33: 2793-2799.

BRADSHAW AD (1984) The importance of evolutionary ideas in ecology - and vice versa. In: Shorroscks B (ed) Evolutionary ecology: 1-25. Blackwell, Oxford, United Kingdom.

BRADSHAW AD \& K HARDWICK (1989) Evolution and stress-genotypic and phenotypic components. Biological Journal of the Linnean Society 37: 137155.

BROOKS RR (1998) Plants that hyperaccumulate heavy metals. Their role in phytoremediation, microbiology, archaeology, mineral exploration and 
phytomining. Cab International, United Kingdom. $380 \mathrm{pp}$.

BROOKS PD, D McNIGHT \& K BENCALA (2001) Annual maxima in $\mathrm{Zn}$ concentrations during spring snowmelt in streams impacted by mine drainage. Environmental Geology 40: 1447-1454.

CARTER V (1996) Technical aspects of wetlands. Wetland hydrology, water quality, and associated functions. United States Geological Survey Water Supply paper 2425, U.S. Geological Survey, USA. $35 \mathrm{pp}$.

CAVIERES LA \& MTK ARROYO (1999) Tasa de enfriamiento adiabático del aire en el Valle del Río Molina, Provincia de Santiago, Chile central $\left(33^{\circ}\right.$ S). Revista Geográfica de Chile Terra Australis 44: 79-86

CEPEDA J \& MC MORALES (2006) Limnología del humedal Tambo-Puquíos. In: Cepeda PJ (ed) Geología de los Andes desérticos. La alta montaña del Valle del Elqui: 415-471. Ediciones Universidad de La Serena, La Serena, Chile.

CEPEDA J, F SQUEO \& A CORTÉS (2006) La biota del humedal Tambo-Puquíos. In: Cepeda PJ (ed) Geología de los Andes desérticos. La alta montaña del Valle del Elqui: 243-283. Ediciones Universidad de La Serena, La Serena, Chile.

CHAMBERS JC (1997) Restoring alpine ecosystems in the western United States: environmental constraints, disturbance characteristics, and restoration success. In: Urbanska KM, NR Webb \& PJ Edwards (eds) Restoration ecology and sustainable development: 161-187. Cambridge University Press, Cambridge, United Kingdom.

CLOW DW \& JK SUEKER (2000) Relations between basin characteristics and stream water chemistry in alpine/subalpine basins in Rocky Mountain National Park, Colorado. Water Resources Research 36: 49-61.

CORREA NM (1978) Flora Patagónica. Parte III. Colaboración Científica Instituto Nacional de Tecnología Agropecuaria (INTA). Buenos Aires, Argentina. 569 pp.

DENNINSON WC, RJ ORTH, KA MOORE, JC STEVENSON, V CARTER, S KOLLAR, PW BERGSTROM \& RA BATIUK (1993) Assessing water quality with submersed aquatic vegetation. Bioscience 43: 86-94.

DI CASTRI F \& E HAJEK (1976) Bioclimatología de Chile. Santiago, Chile. Ediciones de la Pontificia Universidad Católica de Chile, Santiago, Chile. 163 pp.

DINELLI E, F LUCCHINI, M FABBRI \& G CORTECCI (2001) Metal distribution and environmental problems related to sulfide oxidation in the Libiola copper mine area (Ligurian Apennines, Italy). Journal of Geochemical Exploration 74: 141-152.

DOLD B \& L FONTBOTÉ (2001) Element cycling and secondary mineralogy in porphyry copper tailing as a function of climate, primary mineralogy, and mineral processing. Journal of Geochemical Exploration 74: 3-55.

DRAPER NR \& H SMITH (1998) Applied regression analysis. John Whiley \& Sons Inc., New York, New York, USA. $706 \mathrm{pp}$

EHRENFELD JG \& JP SCHNEIDER (1991) Chamaecyparis thyoides wetlands and suburbanization. Effects on hydrology water quality and plant community composition. Journal of Applied Ecology 28: 467-490.

EVANGELOU VP (2001) Pyrite microencapsulation technologies: principles and potential field application. Ecological Engineering 17: 165-178.

FERNÁNDES JC \& FS HENRÍQUES (1991) Biochemical, physiological, and structural effects of excess copper in plants. The Botanical Review 57: 246273.

GAJARDO R (1994) La vegetación natural de Chile. Clasificación y distribución geográfica. Editorial Universitaria, Santiago, Chile. 165 pp.

GINOCCHIO R \& AJM BAKER (2004) Metallophytes in Latin America: a remarkable biological genetic resource scarcely known and studied in the region. Revista Chilena de Historia Natural 77: 185-194.

GINOCCHIO R, I TORO, D SCHNEPF \& MR MACNAIR (2002) Copper tolerance in populations of Mimulus luteus var. variegatus exposed and non-exposed to copper pollution. Geochemistry, Exploration, Environment, Analysis 2: 151-156.

GRAY NF (1996) A substrate classification index for the visual assessment of the impact of acid mine drainage in lotic systems. Water Research 6: 15511554.

GRAY NF (1998) Acid mine drainage composition and the implications for its impact on lotic systems. Water Research 32: 2122-2134.

HARPER FA (1996) The cost of copper tolerance in Mimulus guttatus. Ph.D. thesis, University of Exeter, Exeter, United Kingdom. 150 pp

HARRISON BJ (1998) Copper information sourcebook: 1998. Internacional Copper Association Ltd., New York, New York, USA. 478 pp.

HENRÍQUEZ H (1974) Prospección hidrogeoquímica en el sector adyacente a la mina Río Blanco, Compañía Minera Andina S.A., Provincia de Aconcagua, Chile. IIG \& Compañía Minera Andina, Santiago, Chile. 10 pp.

HOFFMANN A, MTK ARROYO, F LIBERONA, M MUÑOZ \& J WATSON (1998) Plantas altoandinas en la flora silvestre de Chile. Ediciones Fundación Claudio Gay, Santiago, Chile. 281 pp.

JONGMAN RHG, CJF TER BRAAK \& OFR VAN TONGEREN (1995) Data analysis in Community and Landscape Ecology. Cambridge University Press, Cambridge, United Kingdom. 299 pp.

KENT M \& P COKER (1994) Vegetation description and analysis. A practical approach. John Wiley and Sons, Chichester, New York, USA. 363 pp.

KONTOPOULOS A (1998) Acid mine drainage control. In: Castro SH, Vergara F, Sánchez MA (eds) Proceedings of the IV international conference on clean technologies for the mining industry: 27-42. Santiago, Chile.

KÖRNER C (2003) Alpine plant life. Functional plant ecology of high mountain ecosystems. SpringerVerlag, Heidelberg, Germany. 344 pp.

KRUCKEBERG AL \& L WU (1992) Copper tolerance and copper accumulation of herbaceous plants colonizing inactive California copper mines. Ecotoxicology and Environmental Safety 23: 307-319.

LEPS J \& P SMILAUER (2003) Multivariate analysis of ecological data using CANOCO. Cambridge University Press, Cambridge, United Kingdom. 269 pp.

LUEBERT F \& P PLISCOFF (2006) Sinopsis bioclimática y vegetacional de Chile. Editorial Universitaria, Santiago, Chile. 316 p.

MACNAIR MR \& AJM BAKER (1994) Metal-tolerant plants: an evolutionary perspective. In: Farago ME (ed) Plants and the chemical elements: $67-85$. VCH, Weinheim, Germany . 
OSORIO R, R CABEZAS, H REYES, P ÁLVAREZ \& H ZAVALA (2006) Humedales altoandinos de la IV Región. In: Cepeda PJ (ed) Geoecología de los Andes desérticos. La alta montaña del valle del Elqui: 153-239. Ediciones Universidad de La Serena, La Serena, Chile.

PEPPAS A, K KOMNITSAS \& I HALIKIA (2000) Use of organic covers for acid mine drainage control. Minerals Engineering 13: 563-574.

PETERS A, WJ ADAMS, ML DIAMOND, W DAVISON, DM DI TORO, PJ DOYLE, D MACKAY, J NRIAGU, C PTACEK, JM SKEAFF, E TIPPING \& H WAETERSCHOOT (2007) Integrated approach for hazard assessment of metals and inorganic metal substances: the unit world model approach. In: Adams WJ \& Chapman PM (eds) Assessing the hazard of metals and inorganic substances in aquatic and terrestrial systems: 11-54. SETAC Press, Pensacola, Florida, USA.

PUCKETT LJ \& OP BRICKER (1992) Factors controlling the major ion chemistry of streams in the Blue Ridge and Valley and Ridge physiographic provinces of Virginia and Maryland. Hydrological Processes 6:n79-98.

RAUNKIAER C (1937) Plant life forms. Oxford University Press, London, United Kingdom. 104 pp.

RICE KC \& OP BRICKER (1995) Seasonal cycles of dissolved constituents in stream water in two forested catchments in the mid-Atlantic region of the eastern USA. Journal of Hydrology 171: 137-158.

RITCEY GM (1989) Tailings management: problems and solutions in the mining industry. Elsevier, New York, New York, USA. 1,000 pp.

RUTHSATZ B (1993) Flora and ecological conditions of high Andean mires of Chile between $18^{\circ} 00^{\prime}$ (Arica) and 40³0' (Osorno) S Lat. Phytocoenología 23: 157-199.

SANTIBÁÑEZ F \& M URIBE (1993) Atlas agroclimático de la V Región y Región Metropolitana. Universidad de Chile, Facultad de Ciencias Agrarias y Forestales, Ministerio de Agricultura, Fondo de Investigación Agropecuaria, Corporación Nacional de Fomento, Santiago, Chile. 65 pp.

SCHAT H \& WM TEN BOOKUM (1992) Genetic control of copper tolerance in Silene vulgaris. Heredity 68 : 219-229.

SERRANO L, R VARGAS, V STAMBUK, C AGUILAR, J BLONDEL, M GALEB, C HOLMGREN, A CONTRERAS, S GODOY, I VELA, MA SKEWES \& CHR STERN (1994) The late Miocene Río Blanco - Los Bronces copper deposit, central Chilean Andes. In: Camus F, Sillitoe RH and Petersen R (eds) Andean copper deposits: new discoveries, mineralizations, styles and metallogeny: 119-130. Society of Economic Geologists, Special Publication $\mathrm{N}^{\circ}$ 5, Littleton, Colorado, USA.

SKEWES MA \& CR STERN (1994a) Tectonic trigger for the formation of late Miocene $\mathrm{Cu}$-rich breccia pipes in the Andes of central Chile. Geology 22: 551-554.

SKEWES MA \& CR STERN (1994b) Late Miocene copper deposits, magmatism and tectonics in the Andes of central Chile. Actas $7^{\circ}$ Congreso Geológico Chileno, vol II, Universidad de Concepción, Concepción, Chile. pp 1620-1622.

SQUEO FA, H VEIT, G ARANCIO, JR GUTIÉRREZ, MTK ARROYO \& N OLIVARES (1993) Spatial heterogeneity of high mountains vegetation in the Andean desert zone of Chile. Mountain Research and Development 13: 1-10.
SQUEO FA, R OSORIO \& G ARANCIO (1994) Flora de los Andes de Coquimbo: cordillera de Doña Ana. Ediciones Universidad de La Serena, La Serena, Chile. 176 pp.

SQUEO FA, $\mathrm{N}$ OLIVARES, $\mathrm{S}$ OLIVARES, A POLLASTRI, E AGUIRRE, R ARAVENA, C JORQUERA \& JR EHLERINGER (1999) Grupos funcionales en arbustos desérticos definidos en base a las fuentes de agua utilizadas. Gayana Botánica (Chile) 56: 1-16

SQUEO FA, J CEPEDA, NC OLIVARES \& MTK ARROYO (2006a) Interacciones ecológicas en la alta montaña del Valle del Elqui. In: Cepeda PJ (ed) Geología de los Andes desérticos. La alta montaña del Valle del Elqui: 69-103. Ediciones Universidad de La Serena, La Serena, Chile.

SQUEO FA, E IBACACHE, BG WARNER, D ESPINOZA, R ARAVENA \& JR GUTIÉRREZ (2006b) Productividad y diversidad florística de la vega Tambo, Cordillera de Doña Ana. In: Cepeda PJ (ed) Geología de los Andes desérticos. La alta montaña del Valle del Elqui: 325-351. Ediciones Universidad de La Serena, La Serena, Chile.

SQUEO FA, GG WARNER, R ARAVENA \& D ESPINOZA (2006c) Bofedales: high altitude peatlands of the central Andes. Revista Chilena de Historia Natural 79: 245-255.

STEUBING L (1982) Problems of bioindication and the necessity of standardization. In: Steubing L \& HJ Jäger (eds) Monitoring air pollutants by plants: 1927. Dr. Junk Publishers, The Hague, The Netherlands

STEWART AJA, EA JOHN \& MJ HUTCHINGS (2000) The world is heterogeneous: ecological consequences of living in a patchy environment. In: Hutchings MJ, EA John \& AJA Stewart (eds) The ecological consequences of environmental heterogeneity: 1-8. Blackwell Science, Oxford, United Kingdom.

STOUGHTON JA \& WA MARCUS (2000) Persistent impacts of trace metals from mining on floodplain grass communities along Soda Butte Creek, Yelowstone National Park. Environmental Management 25: 305-320.

TEILLIER S (2005) Contribución al conocimiento de la flora y la vegetación de las vegas de la cuenca del río de Las Taguas, departamento Iglesias, San Juan, Argentina. Chloris Chilensis, 2. URL: www.chlorischile.cl

TER BRAAK CJF (1986) Canonical correspondence analysis: a new eigenvector technique for multivariate direct gradient analysis. Ecology 67: 1167-1179.

TER BRAAK CJF (1995) Ordination. In: Jongman RHG, CJF Ter Braak \& OFR Van Tongeren (eds) Data analysis in community and landscape ecology: 91173. Cambridge University Press, Cambridge, United Kingdom.

TER BRAAK CJF \& \& P $\square$ SMILAUER (2002) CANOCO reference manual and CanoDraw for windows user's guide: software for canonical community ordination (version 4.5). Microcomputer Power, Ithaca, New York, USA. 500 pp.

TYLER G, AMB PAHLSSON, G BENGTSSON, E BAATH \& L TRANVIK (1989) Heavy metal ecology of terrestrial plants, microorganisms and invertebrates. Water, Air and Soil Pollution 47: 189-215.

U.S. ENVIRONMENTAL PROTECTION AGENCY (1996) Microwave-assisted acid digestion of siliceous and 
organically based matrices. SW-846 Method 3052 . National Technical Information Service, Washington, District of Columbia, USA. 20 pp.

UNITED STATES ENVIRONMENTAL PROTECTION AGENCY (1997) Test methods for evaluating solid waste - Physical/chemical methods, Method SW846. Department of Commerce, National Technical Information Service, Springfield, Virginia, USA. $1,000 \mathrm{pp}$.

UNITED STATES ENVIRONMENTAL PROTECTION AGENCY (1999) National recommended water quality criteria - corrected. EPA Publication 822-Z99-001. Office of Water, National Technical Information Service, USA. 26 pp.

VILLAVICENCIO G, P URRESTARAZU, C CARVAJAL, KAC DE SCHAMPHELAERE, CR JANSSEN, JC TORRES \& PH RODRÍGUEZ (2005) Biotic ligand model prediction of copper toxicity to Daphnids in a range of natural waters in Chile. Environmental Toxicology and Chemistry 24: 1287-1299.
WHEELER BD \& MCF PROCTOR (2000) Ecological gradients, subdivisions and terminology of northwest European mires. Journal of Ecology 88: 187203.

WHEELER BD, MM AL-FARRAJ \& RED COOK (1985) Iron toxicity to plants in base-rich wetlands: comparative effects on the distribution and growth of Epilobium hirsutum L. and Juncus subnodulosus Schrank. New Phytologist 100: 653-669.

WHEELER BD, RP MONEY \& SC SHAW (2002) Freshwater wetlands. In: Perrow MR \& AJ Davy (eds) Handbook of ecological restoration: 325-354. Cambridge University Press, Cambridge, United Kingdom.

WILSON SD (2000) Heterogeneity, diversity and scale in plants communities. In: Hutchings MJ, EA John \& AJA Stewart (eds) The ecological consequences of environmental heterogeneity: 53-69. Blackwell Science, Oxford, United Kingdom.

ZAR JH (1984) Biostatistical analysis. Prentice-Hall Inc., Englewood Cliffs, New Jersey, USA. 718 p. 